\section{AGRIEKONOMIKA}

http://journal.trunojoyo.ac.id/agriekonomika

Volume 9, Nomor 1, 2020

https://doi.org/10.21107/agriekonomika.v9i1.6928
Agriekonomika has been accredited as a scientific journal by the Ministry of

Research-Technology and Higher

Education Republic of Indonesia: No. 23/E/KPT/2019

\title{
Strategi Peningkatan Nilai Tambah Perkebunan Karet \\ Melalui Diversifikasi Usaha
}

SINTA 2

$凶$ Junaidi

Balai Penelitian Sungei Putih, Pusat Penelitian Karet

Galang, Deli Serdang, Indonesia

Received: January 2020; Accepted: April 2020; Published: April 2020

\begin{abstract}
ABSTRAK
Pendapatan petani dan perusahaan perkebunan karet belum optimal karena harga komoditi karet fluktuatif. Diversifikasi usaha menjadi salah satu strategi untuk meningkatkan produktivitas lahan dan nilai ekonomi perkebunan karet. Tujuan tulisan review ini adalah (1) mendeskripsikan strategi peningkatan nilai tambah perkebunan karet melalui diversifikasi usaha, (2) menyajikan sistem tumpangsari berbasis karet, integrasi karet-ternak, pemanfaatan biji karet, ekstraksi protein lateks, dan pemanfaatan kayu karet sebagai alternatif untuk memperoleh keuntungan yang optimal. Jarak tanam yang renggang dapat dimanfaatkan sebagai sumber pendapatan dengan pola tumpangsari selama tanaman belum menghasilkan (TBM). Peningkatan nilai tambah lainnya dapat dilakukan dengan integrasi karet-ternakmemanfaatkan gulma di areal perkebunan karet sebagai pakan. Endosperm biji karet dapat diolah menjadi tepung pakan dan biodiesel, sedangkan cangkang biji dapat diproses menjadi karbon aktif yang memiliki nilai ekonomis tinggi. Pemanfaatan sumberdaya non-lateks selain meningkatkan nilai tambah kebun, juga dapat digunakan sebagai alternatif sumber pendapatan untuk meminimalisir dampak harga karet yang rendah.
\end{abstract}

Kata kunci: Strategi, Peningkatan, Nilai Ekonomi, Perkebunan Karet

Strategies for Increasing Value Added of Rubber Plantation Through Diversification

\begin{abstract}
The rubber farmers and companies income has not been optimal as the rubber price is volatile. Business diversification is one of the strategies for increasing land productivity and the economic value of rubber plantations. The aim of this review are (1) describing the strategies for increasing the added value of rubber plantations through business diversification, (2) elaborating the rubber-based intercropping system, rubber-livestock integration, seed processing, latex's protein extraction, and rubberwood utilazation as alternatives to obtain optimal profit. The wide-planting space can be used as a source of income through intercropping during the immature period. Other strategies including rubber-livestock integration, utilizing weeds in the area of rubber plantations. Rubber seed endosperm can be processed into feed flour and biodiesel, while the seed shells can be processed into activated carbon which has high economic value. Non-latex resources not only can increase the added value of rubber plantations, but also as an alternative source of income to minimize the impact of low rubber prices.
\end{abstract}

Keywords: Strategy, Increasing, Economic Value, Rubber Plantations 


\section{PENDAHULUAN}

Tanaman karet (Hevea brasiliensis) di Indonesia menjadi sumber pendapatan devisa negera dan juga petani, namun harga karet berfluktuasi dan cenderung rendah (Nancy dkk., 2013; Syarifa dkk., 2016, dan Sahuri, 2019). Luas tanaman karet mencapai 3,5 juta hektar Badan Pusat Statistik (2019), sehingga dapat diusahakan melalui integrasi karet-ternak dan berpengaruh signifikan terhadap pendapatan petani. Tanaman karet merupakan spesies penghasil utama karet alam. Tanaman lain seperti guayule (Parthenium argentatum), Russian dandelion (Taraxacum koksaghyz), lettuce (Lactuca serriola), dan fig tree (Ficus bengalensis) juga dapat menghasilkan karet namun produktivitasnya jauh di bawah $H$. Brasiliensis (Mooibroek dan Cornish, 2000; Venkatachalam dkk., 2013). Partikel karet disintesis dalam sel laticifer, sel khusus yang dimiliki oleh lebih dari 2.500 spesies penghasil latex (Hayashi, 2009).

Karet alam dapat diolah menjadi ribuan produk turunan, dari peralatan industri, transportasi, kesehatan, sampai perlengkapan rumah tangga. Pada tahun 2018 diperkirakan produksi karet alam dunia mencapai 13,89 juta ton dengan konsumsi mencapai 13,81 juta ton (Malaysian Rubber Board, 2019). Sebagian besar tanaman karet terkonsentrasi di Asia Tenggara dimana Indonesia dan Thailand merupakan dua negara yang mendominasi pasokan karet alam dunia.Tanaman karet umumnya dibudidayakan dalam bentuk perkebunan, baik skala kecil dalam bentuk perkebunan karet rakyat maupun skala luas berupa perkebunan besar negara dan swasta. Lateks adalah bagian tanaman yang paling bernilai ekonomis danmerupakan sumber pendapatan utama bagi petani dan perusahaan perkebunan karet. Pada tahun 2013 harga karet merosot, Baffes dan Wu (2018), mencatat bahwa pada periode Juli 2017- Desember 2018, harga karet mengalami titik terendah pada Desember 2018. Sedangkan Pai (2019), melaporkan bahwa selama tahun 2019 harga karet cenderung stagnan.
Kondisi ini sangat memukul agribisnis karet, tidak hanya di Indonesia namun di seluruh negara produsen karet alam.

Petani dan perusahaan perkebunan karet mengalami kerugian karena sangat bergantung pada produksi lateks. Harga karet sangat berpengaruh terhadap daya beli dan kondisi sosial ekonomi petani karet (A'ini dan Jannah, 2016; Syarifa dkk., 2016), sedangkan ditingkat perusahaan perkebunan komoditi karet terus mengalami kerugian setiap tahunnya. Menghadapi kondisi ini, petani karet umumnya beralih ke profesi lain yang lebih menjanjikan, sementara perusahaan perkebunan ber-upaya menekan biaya melalui efisiensi pemupukan (Saputra, 2018) dan penerapan sistem sadap intensitas rendah (Nugrahani dkk., 2017; Widyasari dkk., 2017). Tenaga kerja merupakan komponen biaya paling besar di perkebunan karet, mencapai $+61 \%$ dari total biaya operasional (Hirohata dan Fukuyo, 2011; Hirohata, 2015). Dari total biaya tenaga kerja, tenaga penyadap termasuk komponen paling besar (Agustina dkk., 2013).

Pengembangan sumber daya manusia merupakan proses untuk meningkatkan pengetahuan, kreativitas dan keterampilan, serta kemampuan dalam berusaha untuk meningkatkan derajat ekonomi petani (Dewi dkk., 2010 dan Rusdiana dan Praharani, 2018). Untuk mengurangi biaya tenaga kerja, dua pendekatan dilakukan bersamaan yaitu menambah jumlah pohon per hanca dan menurunkan frekuensi penyadapan. Untuk menghindari pemutusan hubungan kerja (PHK), tenaga kerja yang ada perlu diberdayakan agar tetap produktif bagi perusahaan. Untuk itu, upayameningkatkan pendapatan dari kebun karet di samping pendapatan utama dari lateks perlu dipertimbangkan.Upaya memanfaatkan sumber pandapatan nonlateks telah banyak diteliti, misalnya pengolahan biji karet sebagai sumber minyak nabati Ahmad dkk. (2014), Jisieike dkk. (2020), dan pengolahan cangkang biji menjadi arang aktif yang bernilai ekonomis tinggi (Anis dkk., 2014; dan Pagketanang 
dkk., 2015).

Berdasarkan permasalahan tersebut di atas, areal tanaman karet dapat memberikan nilai tambah dengan pola tumpangsari, wanatani, atau integrasi dengan kegiatan agribisnis lainnya. Hingga saat ini, sumber pendapatan non-lateks belum banyak dimanfaatkan. Penguasaan teknologi, kepastian pasar, dan keterbatasan modal masih menjadi hambatan dalam mengelola sumber perdapatan non-lateks. Tujuan tulisan review ini adalah (1) mendeskripsikan strategi meningkatkan nilai tambah perkebunan karet melalui diversifikasi usaha dan (2) menyajikan usaha melalui tumpangsari berbasis karet, integrasi karet-ternak, pemanfaatan biji karet, ekstraksi protein lateks, dan pemanfaatan kayu karet sebagai faktor utama untuk keberhasilan usaha.

\section{Tumpangsari Berbasis Karet}

Pendapatan petani dan perkebunan karet belum optimal karena harga komoditi fluktuatif, usaha tumpangsari menjadi salah satu strategi dalam meningkatkan produktivitas lahan dan nilai ekonomi petani karet (Sahuri, 2019). Tanaman karet dapat mulai disadap jika lilit batang (pada ketinggian $100 \mathrm{~cm}$ dari pertautan okulasi) mencapaiminimal $45 \mathrm{~cm}$. Namun dengan kondisi harga karet yang rendah, buka sadap disarankan lebih dari $45 \mathrm{~cm}$, semakin besar lilit batang maka semakin tinggi potensi produksi getah karet yang dihasilkan (Agustina dkk., 2017 dan Rinojati dkk., 2018). Dengan pemeliharaan standar lilit batang $45 \mathrm{~cm}$ dapat dicapai antara 4-5 tahun dan masih dapat dipercepat melalui persiapan lahan dan bibit yang prima serta pemeliharaan intensif (Boerhendy dkk., 2012). Selama masa tanaman belum menghasilkan (TBM), praktis tidak ada pendapatan dari tanaman karet.Strategi usaha pertanian dengan pola tumpangsari dilakukan dalam rangka memperoleh pendapatan, namun tidak mengganggu pertumbuhan dan perkembangan tanaman karet.

Jarak tanam karet yang renggang dapat dimanfaatkan sebagai sumber pendapatan dengan pola tumpangsari selama tajuk antar barisan belum bertemu antara 3-4 tahun. Produktivitas beberapa tanaman sela di bawah tegakan karet disajikan pada Tabel 1. Selain sebagai sumber pendapatan, tumpangsari juga berguna untuk menekan pertumbuhan gulma. Namun demikian, tanaman bergetah dari keluarga Euphorbiaceae tidak dianjurkan sebagai tanaman sela karena dapat menjadi inang Rigidoporus microporus, penyebab penyakit jamur akar putih (JAP). Hasil penelitian Nugroho et al. (2009) menunjukkan tanaman karet yang ditumpangsarikan dengan ubi kayu (Manihot esculenta) memiliki persentase serangan JAP lebih tinggi dibanding areal yang tidak ditanami ubi kayu. Jarak tanam dapat didesain sehingga tumpangsari dapat dilakukan dalam jangka panjang. Rodrigo dkk. (2004), menyimpulkan bahwa baris ganda (double rows) merupakan pola tanam terbaik untuk tumpangsari berbasis karet. Lebih lanjut, penelitian Sahuri (2017), menunjukkan jarak tanam ganda dengan jarak antara baris ganda $18 \mathrm{~m}$, jarak antara baris sempit $2 \mathrm{~m}$, dan jarak antara tanaman 2,5 m (populasi 400 tanaman/ha) sangat sesuai untuk tumpangsari jangka panjang.

Secara umum, teknis budidaya tanaman sela di bawah tegakan karet tidak jauh berbeda dengan pola tanam monokultur, sehingga dalam hal kultur teknis tidak ada hambatan. Sistem tumpangsari dapat dikelola secara mandiri oleh perusahan atau kerjasama dengan karyawan atau koperasi karyawan, petani atau kelompok tani, atau perusahaan lain dengan sistem bagi hasil. Strategi pemilihan jenis komoditi, penyesuaian dengan pola musim, dan permintaan pasar menjadi kunci keberhasilan tumpangsari. Kendala utama adalah kepastian pasar baik dalam daya serap pasar maupun tingkat harga. Hal ini sangat penting untuk memastikan hasil panen dapat dipasarkan dan memperoleh keuntungan. Untuk mengantisipasi fluktuasi harga komoditi, sistem gilir tanam (relay cropping) dapat dipertimbangkan sebagai alternatif. Gaba 
Tabel 1

Produktivitas Tanaman Sela di Bawah Tegakan Karet

\begin{tabular}{lcl}
\hline Tanaman sela & Produktivitas (kg/ha) & Referensi \\
\hline Kedelai (Glycine max) & 1.000 & Sundari dan Purwantoro (2014) \\
Jagung (Zea mays) & 1.246 & Sahuri (2017b) \\
Sorgum (Sorghum bicolor) & 1.800 & Sahuri (2017c) \\
Kakao (Theobroma cacao) & 1.000 & Zakariyya et al. (2016) \\
Padi (Oryza sativa) & 2.800 & Sahuri et al. (2016) \\
Pisang (Musa acuminata) & 5.225 & Rinojati et al. (2016) \\
Cabai (Capsicum annuum) & 6.750 & Sahuri dan Rosyid (2015) \\
Bangun-bangun (Coleus amboinicus) & 2.954 & Andriyanto et al. (2017) \\
\hline
\end{tabular}

Sumber: Data Sukender Diolah, 2019

dkk. (2015), menjelaskan bahwa pola gilir tanam juga berguna untuk meningkatkan efisiensi pemupukan, pemanfaatan air, menekan penggunaan pestisida.

\section{Integrasi Karet-Ternak}

Pada areal tanaman karet yang yang masih muda, areal gawangan biasanya ditanami kacangan penutup tanah.Namun seiring tajuk yang mulai menutup, dengan sendirinya kacangan penutup tanah akan digantikan berbagai spesies gulma. Untuk mengendalikan gulma, dibutuhkan biaya yang besar karena dalam satu tahun diperlukan 3-4 kali rotasi. Pengendalian gulma dengan sistem blanket sehingga areal bebas gulma sama sekali (Gambar 1A) dari sisi lingkungan kurang baik karena meningkatkan erosi (Liu dkk., 2019), dan menghilangkan keragaman hayati (Valdes, 2016). Ditambah lagi, penggunaan herbisida yang berlebihan dapat mencemari lingkungan (Kughur, 2012). Harga karet yang rendah saat ini menyebabkan banyak perkebunan karet mengurangi rotasi pengendalian, sehingga gulma tumbuh subur.Gulma di areal perkebunan karet sangat potensial dimanfaatkan sebagai sumber pakan ternak (Dianita, 2012).

Hewan ternak seperti sapi (Gambar 1B) dan kambing umum dipelihara di lingkungan sekitar kebun. Spesies gulma di perkebunan karet yang dapat digunakan sebagai pakan ternak antara lain: Axonopus compressus, Ottochloa nodosa, Ageratum conyzoides, Mimosa pudica, Mikania michrantha, dan Asystasia gigantica (Sari dan Rahayu, 2013). Penelitian Hutapea dkk. (2019), menunjukkan bahwa komposisi $10 \%$ rumput segar dari perkebunan karet dan 1\% konsentrat dapat memberikan pertambahan berat badan sapi hingga $0,36 \mathrm{~kg} / \mathrm{hari}$, terbaik dibanding perlakuan lain yang diujicobakan. Diwyanto dkk. (2007), menyatakan bahwa melalui pendekatan low external input sustainable agriculture (LEISA), lahan pertanian dapat menghasilkan pakan untuk memelihara sapi sebanyak 2-3 ekor/ha, sedangkan analisis yang dilakukan oleh Rusdiana dkk. (2015), menunjukkan bahwa usaha ternak sapi potong dengan cara digembalakan di lahan perkebunan kelapa sawit dan karet memiliki $\mathrm{R} / \mathrm{C}$ ratio 1,2 sehingga cukup potensial dikembangkan dalam skala luas.

Lahan perkebunan karet dapat dimanfaatkan sebagai lahan penggembalaan sapi potong bekerjasama dengan pemilik perkebunan. Agar kegiatan usaha berjalan dengan baik, maka pemilik kebun dan petani dapat membuat kesepakatan bersama. Artinya, kedua belah pihak saling memahami mekanisme pembagian hasil, baik secara lisan maupun tertulis. Usaha sapi potong yang diintegrasikan dengan tanaman karet secara ekonomi dapat dihitung untung ruginya. Hasil penelitian yang dilakukan olehRusdiana et al. (2010) dan Rusdiana dan Soeharsono (2017) menunjukkan bahwa semakin tinggi skala pemeliharaan sapi potong produktif, maka indeks efisiensi ekonomi dan keuntungan yang diperoleh petaniakan semakin 

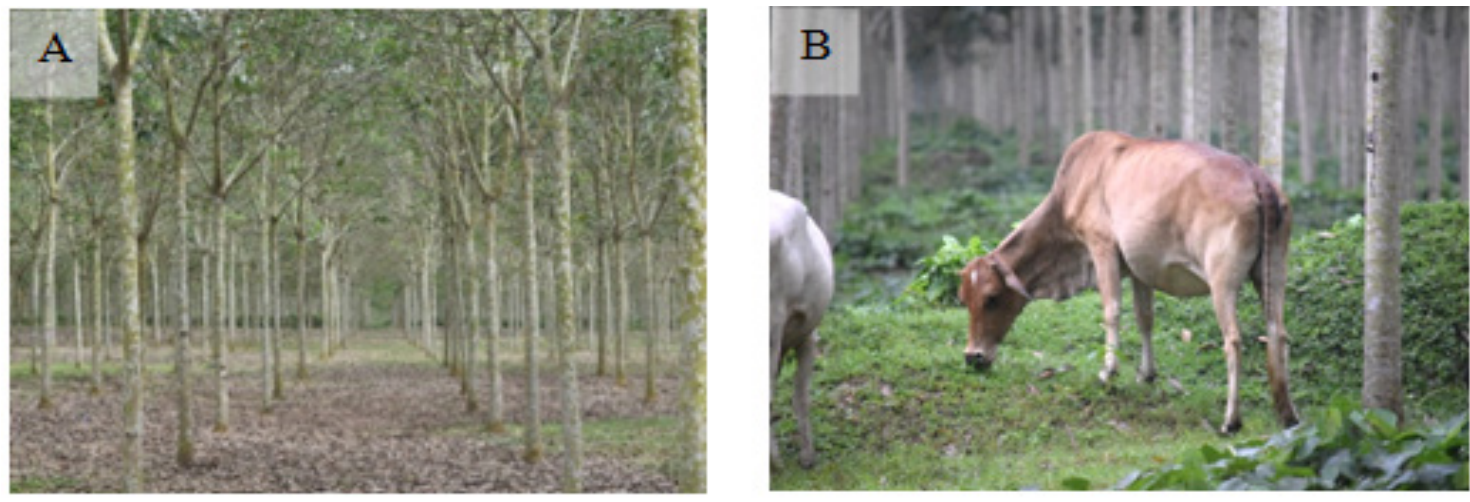

Gambar 1

Areal Gawangan Tanaman Karet yang Bersih dari Gulma (A). Ternak Sapi Digembalakan di Perkebunan Karet (B)

Tabel 2

Analisis Ekonomi Usaha Sapi Potong di Tingkat Petani

\begin{tabular}{lcc}
\hline \multirow{2}{*}{ Uraian } & \multicolumn{2}{c}{ Lokasi penggembalaan } \\
\cline { 2 - 3 } & Lahan perkebunan sawit dan karet & Lahan tegalan dan sawah \\
\hline Biaya produksi & 38.070 .000 & 23.462 .500 \\
Kenuntungan kotor & 41.255 .000 & 27.000 .000 \\
Keuntungan bersih & 3.185 .000 & 3.637 .500 \\
R/C & 1,2 & 1,2 \\
\hline Sur
\end{tabular}

Sumber: Rusdiana dan Soeharsono, 2017

meningkat. Koefisien ekonomi usaha sapi potong di tingkat petani dihitung dengan asumsi rata-rata skala pemeliharaan 2-3 ekor induk dengan jangka waktu untuk produksi antara 1,5-2 tahun. Biaya pakan dapat diasumsikan kedalam biaya tenaga kerja, karena selama pemeliharaan sapi potong digembalakan. Biaya penyusutan bibit sapi dan kandang diasumsikan selama 5 tahun. Adapun peralatan kandang, obatobatan, dan biaya lainnya diasumsikan kedalam biaya produksi. Nilai keuntunagn petani pada usaha sapi potong dengan sistem digembalakan di lahan perkebunan sawit, karet, tegalan dan sawah habis panen disajikan pada Tabel 2 .

Kebun karet selain menghasilan lateks, rumput sebagai pakan ternak, juga berpotensi untuk budidaya lebah madu memanfaatkan musim bunga. Razak dkk. (2016), merekomendasikan usaha ternak lebah madu sebagai salah satu sumber pendapatan tambahan bagi petani karet di Malaysia. Wongsiri dkk. (1999), melaporkan bahwa spesies lebah Apis cerana memiliki produktivitas mencapai $6,2 \mathrm{~kg} / \mathrm{sarang} /$ panen sehingga potensial dikembangkan di perkebunan karet. Kendala yang perlu diantisipasi adalah tanaman karet hanya berbunga satu atau dua kali per tahun dengan periode sangat singkat sekitar 1015 hari (Priyadarshan, 2011), sehingga bunga karet tidak dapat dijadikan satusatunya sumber nektar bagi lebah madu. Konsep tenak lebah madu lebih sesuai jika dikombinasikan dengan tumpangsari dan gilir tanam untuk menjamin ketersediaan nektar sepanjang tahun.

\section{Pemanfaatan Biji Karet}

Pemanfaatan utama biji karet selama ini adalah sebagai batang bawah untuk produksi bibit karet dengan metode okulasi. Pada saat harga karet tinggi permintaan bibit karet juga tinggi (Agustina dkk., 2016). Sebaliknya harga karet rendah beberapa tahun terakhir menyebabkan permintaan bibit sangat minim. Biji yang tidak diambil tumbuh di lapangan dan akan menjadi gulma. Untuk menghindari hal tersebut, biji karet dapat diolah menjadi beberapa produk yang benilai ekonomis. 
Endosperm biji dapat diolah menjadi tepung dan digunakan sebagai bahan baku campuran pakan ternak (Oluodo dkk., 2018). Hasil penelitian Syamsunarno dan Sunarno (2014), menunjukkan bahwa tepung biji karet memiliki kandungan nutrisi cukup tinggi (Tabel 3). Adapun kandungan asam sianida ( $\mathrm{HCN}$ ) dalam biji karet dapat diturunkan dengan perlakuan perendaman dan perebusan (Karima, 2015b), pengukusan (Yatno dkk., 2015) atau pemberian abu sekam padi (Fortuna dkk., 2015).Pengolahan biji karet menjadi campuran pakan relatif mudah, beberapa uji coba penggunaan biji karet sebagai alternatif pakan diantaranya pada ayam broiler (Aguihe dkk., 2017), ayam Guinea (Kouassi dkk., 2020), ikan nila (Lee dan Wendy, 2017), ikan patin (Suprayudi dkk., 2015), dan ikan bawal air tawar (Santoso dan Agusmansyah, 2011).

\section{Tabel 3}

Kandungan Nutrisi Tepung Biji Karet Berdasarkan Analisis Proksimat

\begin{tabular}{lcc}
\hline \multirow{2}{*}{ Kandungan } & \multicolumn{2}{c}{ Komposisi (\%) } \\
\cline { 2 - 3 } & Tidak diolah & Diolah \\
\hline Air & 6,06 & 9,39 \\
Protein & 22,90 & 50,74 \\
Lemak & 48,04 & 5,46 \\
Serat kasar & 4,42 & 4,50 \\
Kadar abu & 3,14 & 1,98 \\
Bahan ekstrak & 21,50 & 37,32 \\
tanpa nitrogen & & \\
Total & 100,00 & 100,00 \\
\hline
\end{tabular}

Sumber: Syamsunarno dan Sunarno, 2014

Selain diolah menjadi tepung, endosperm biji karet juga dapat diproses untuk mengekstrak kandungan minyaknya. Minyak biji karet dapat dimanfaatkan diantaranya untuk kosmetik (Nian-Yian dkk., 2014), minyak pangan (Setyawardani dkk., 2013; Karima, 2015a), dan biodiesel (Ahmad dkk., 2014; Ulfah dkk., 2018). Abduh dkk. (2017), menyatakan bahwa pengolahan biji karet menjadi minyak dan biodiesel cukup potensial dikembangkan di daerah dengan sumber biji karet melimpah namun sulit mendapatkan pasokan bahan bakar diesel. Pemrosesan biji karet menjadi biodiesel dapat dilakukan dengan metode non-katalis superheated methanol (Susila, 2009), dan transerifikasi menggunakan asam lemak metil ester sebagai co-solvent (Le dkk., 2018) (Gambar 2).

Cangkang biji karet dapat diproses menjadi karbon aktif yang memiliki nilai ekonomis tinggi.Karbon aktif dari cangkang biji karet telah diteliti untuk digunakan dalam elektroda kapasitor (Pagketanang, dkk., 2015), penanggulangan cemaran logam di perairan (Agarry dan Owabor, 2012 dan Borhan dkk., 2016), serta penyerapan zat pewarna Rodamine B (Nadarajah dkk., 2018). Dalam pembuatan karbon aktif, karbonasi dilakukan dengan pemanasan suhu tinggi. Aulia dkk. (2019), menyatakan bahwa suhu 6000C memberikan hasil lebih baik dibandingkan suhu $4000 \mathrm{C}$ dan $5000 \mathrm{C}$, sedangkan proses aktivasi dapat dilakukan menggunakan karbondioksida (CO2) untuk menghilangkan senyawa fenol (Yan dkk., 2019), kalium hidroksida $(\mathrm{KOH})$ (Pagketanang dkk., 2015), dan zinc klorat ( $\mathrm{ZnCl} 2)$ (Anis dkk., 2014).

Salah satu potensi kendala usaha pemanfaatan biji karet adalah ketersediaan bahan baku secara kontinyu. Seperti halnya musim bunga, musim biji hanya terjadi satu atau dua kali setahun dengan periode sangat singkat (1-2 bulan). Biji karet bersifat rekalsitran dan tidak dapat disimpan lama sehingga pemrosesan harus dilakukan dengan cepat. $\mathrm{Di}$ Indonesia, musim biji berbeda di setiap wilayah tergantung letak geografisnya. Hal ini menjadi keuntungan tersendiri karena untuk memenuhi kebutuhan bahan baku sepanjang tahun, biji dapat didatangkan dari daerah lain yang sedang mengalami musim biji.

\section{Ekstraksi Protein Lateks}

Lateks tanaman karet mengandung senyawa non-karet di antaranya protein, lipid, karotenoid, asam amino, dan unsur logam (Gambar 3) (Ferreira dkk., 2009). Kandungan senyawa-senyawa tersebut bervariasi menurut umur, jenis klon, fenologi, dan intensitas penyadapan 


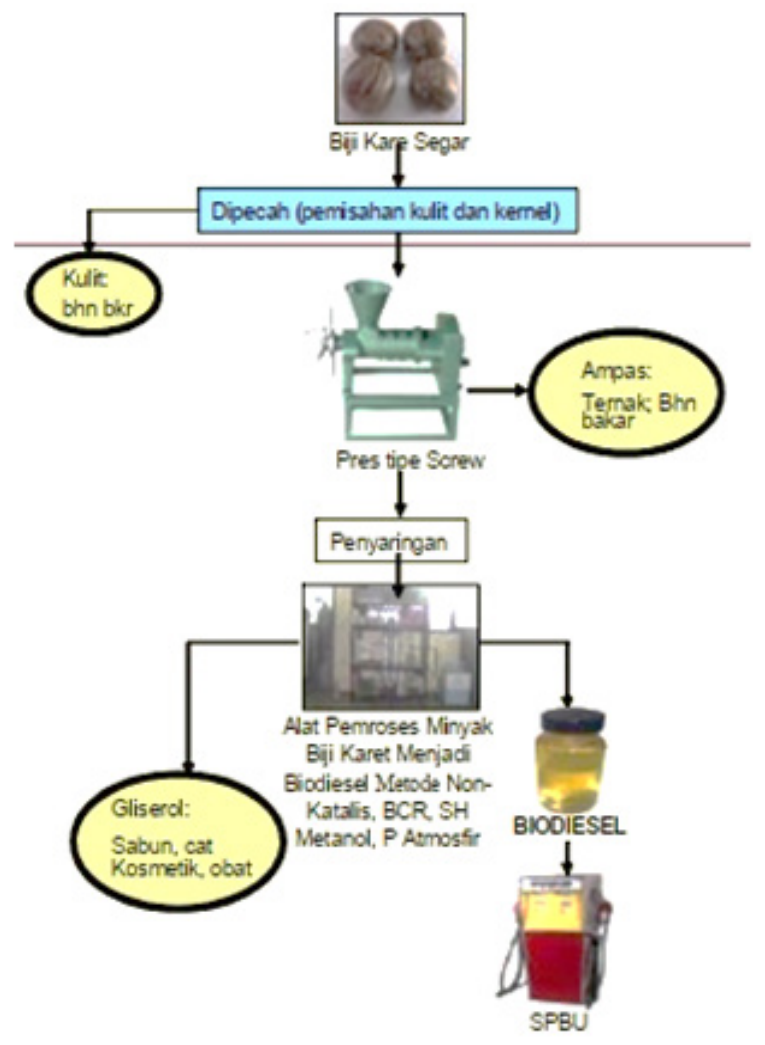

Sumber: Susila, 2009

\section{Gambar 2}

Proses Pengolahan Biji Karet menjadi Biodiesel dengan Metode Non-Katalis di Dalam Bubble Column Reactor (BCR), dan SH Methanol pada Tekanan Atmosfir

yang diterima tanaman (Liengprayoon dkk., 2017). Senyawa protein yang terkandung dalam lateks menyebabkan alergi pada kulit yang sensitif sehingga untuk produk-produk lateks kadar protein harus diturunkan atau dihilangkan (Sussman dkk., 2002). Deproteinisasi dengan perlakuan natrium hidroksida $(\mathrm{NaOH})$, dosis $0,20 \mathrm{phr}$ dapat menurunkan kadar protein sebesar $40,88 \%$ dari lateks kardkkam awal (Darmawan dkk., 2017). Penelitian lainnya oleh Yu dkk. (2019) menunjukkan bahwa penggunaan asam asetat $(\mathrm{CH} 3 \mathrm{COOH})$ dapat menurunkan kandungan protein dalam lateks sebesar $30,07 \%$.

Protein dari limbah pengolahan lateks seperti ribbed smoke sheet (RSS) atau serum hasil penggumpalan lateks dapat diekstraksi dan bernilai ekonomi tinggi. Penelitian ekstraksi protein dari lateks tanaman karet telah banyak dilakukan di antaranya oleh Wang dkk. (2010), melalui metode Borax/PVPP/ Phenol (BPP). Lebih lanjut, Widyarani dkk. (2016), merekomendasikan tahapan hidrolisis protein melalui pemilihan material, seleksi kondisi hidrolisis, dan pemisahan hidrolisat (Gambar 4). Metode ini berpotensi dikembangkan dalam skala industri. Penelitian Tistama dkk. (2017), menunjukkan bahwa koagulasi lateks segar dengan asam format $\left(\mathrm{CH}_{2} \mathrm{O}_{2}\right) 5 \%$ diikuti presipitasi protein dengan aseton dapat menghasilkan jumlah dan kualitas protein yang cukup baik untuk dikembangkan dalam skala lebih besar. Tahir dan Misran (2019), menyatakan bahwa purifikasi protein dari serum lateks dengan metode salting out lebih baik dibandingkan dengan metode sentrifugasi berulang.

Usaha ekstraksi protein ini dapat diaplikasikan di pabrik-pabrik pengolahan lateks sebagai sumber pendapatan non- 


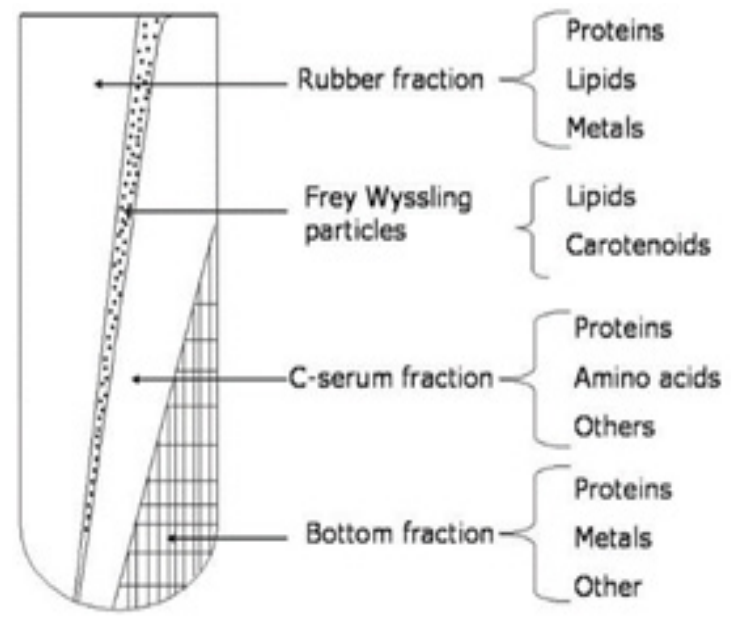

Sumber: Ferreira dkk., 2009

\section{Gambar 3 \\ Kandungan Lateks Tanaman Karet}

karet. Hevein, protein dari lateks tanaman karet berguna sebagai anti-mikroba (Kanokwiroon dkk., 2008) dan anti jamur (Van Parijs dkk., 1991). Jamur Fusarium oxysporum, Collectrotichum capsici dan Rigodoporus microporus dilaporkan peka terhadap aktivitas protein-protein lateks (Tistama dkk., 2017). Dalam skala uji coba, protein Hev-b-13 dari lateks tanaman karet berpotensi digunakan sebagai anti-implamasi (Araújo dkk., 2017) dan berpotensi digunakan dalam pengobatan penyakit degeneratif tulang (Kerche-Silva dkk., 2018). Karena potensi ekonominya cukup tinggi, Omo-lkerodah dkk. (2009), menyarankan kegiatan pemuliaan tanaman untuk merakit klon-klon yang berpotensi menghasilkan protein bermanfaat untuk dikelola dalam skala industri.

\section{Pengolahan Kayu Karet}

Tanaman karet umumnya dibudidayakan selama 25-30 tahun kemudian diremajakan. Kayu karet dapat diolah menjadi bahan baku yang memenuhi kriteria industri kayu dan bernilai ekonomis tinggi (Towaha dan Daras, 2013). Penggunaan kayu karet juga berguna untuk menekan deforestasi (Arsad, 2009). Produk turunan kayu karet di antaranya laminating board, medium density fibreboard (MDF), tripleks, dan arang, sedangkan secara tradisional kayu karet hanya sebagai sumber energi untuk pembuatan batu bata, genteng atau rumah makan (Nancy dkk., 2013) (Gambar 5). Produk MDF dari kayu karet memenuhi syarat mutu SNI No. 014449-2006 dan dapat digunakan untuk menghasilkan berbagai produk furniture (Vachlepi, 2015). Selain itu, kayu karet mempunyai kandungan holoselulosa $67 \%$ dengan ó-selulosa sekitar $40 \%$ sehingga dapat dimanfaatkan sebagai bahan baku pembuatan pulp (Vachlepi, 2019). Penelitian di Brazil menunjukkan bahwa kayu karet dari klon RRIM 600 dan GT 1 memiliki basic density di atas $0,540 \mathrm{~g} / \mathrm{cm}^{3}$, volumetric shrinkage kurang dari $10 \%$, dan compression parallellebih dari $40 \mathrm{MPa}$. Berdasarkan karakteristik tersebut, kayu karet dapat digunakan untuk konstruksi ringan, struktur sekunder, dan industri furnitur (Junior dkk., 2015). Pemanfaatan kayu karet untuk berbagai produk jadi juga dilakukan di negara-negara produsen karet alam lainnya seperti Malaysia dan Thailand (Agustina, 2012). 


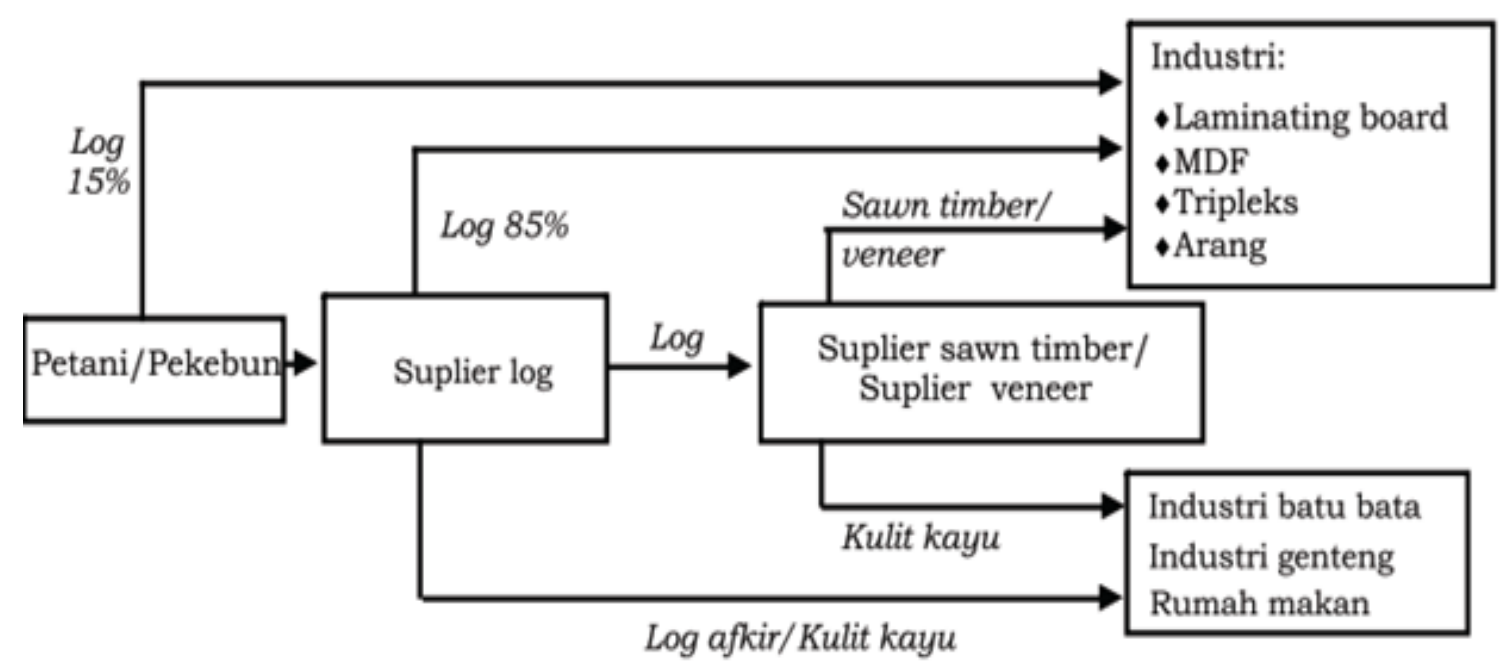

Sumber: Nancy dkk., 2013

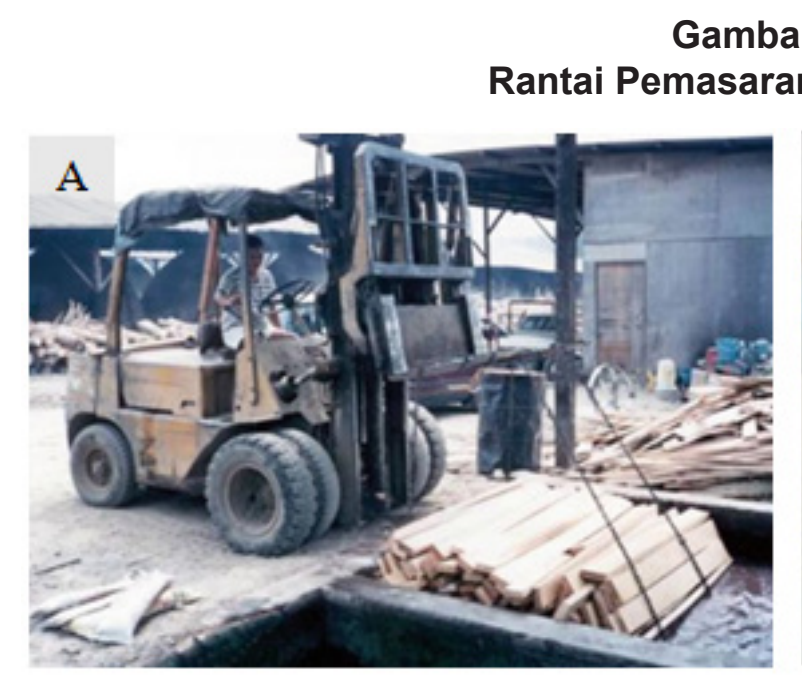

Gambar 5

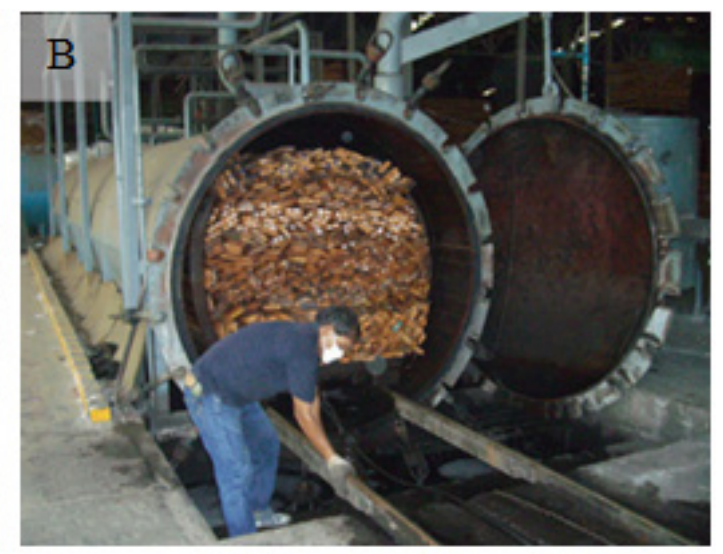

Sumber: Teoh dkk., 2011

\section{Gambar 6 \\ Perendaman dengan Cairan Pengawet (A) dan Vacuum Presure (B) dalam Pengolaan Kayu Karet}

Dalam pengolahan kayu karet, proses pengawetan sangat penting untuk meningkatkan daya simpan kayu karet. Teoh dkk. (2011), menerangkan beberapa metode pengawetan kayu karet di antaranya perendaman dalam senyawa kimia (Gambar 6A), dip-diffusion, pressure treatment, vacuum-pressure (Gambar $6 \mathrm{~B})$, oscillating pressure method (OPM), dan double-vacuum process. Penelitian Suheryanto (2010) menunjukkan bahwa penggunaan cupri sulfat $\left(\mathrm{CuSO}_{4}\right)$ dapat meningkatkan keawetan kayu karet yang meliputi mortalitas, retensi dan derajat kerusakan. Penelitian lainnya oleh Vachlepi dkk. (2015), menunjukkan bahwa penggunaan asap cair dengan metode perendaman selama satu jam dapat meningkatkan daya simpan kayu karet. Pengawetan secara tradiosional juga dapat dilakukan dengan perendaman air dingin, perebusan atau pengukusan (Ismanto dan Saputro, 2014).

Pertumbuhan diamater batang dan kualitas serat kayu sangat dipengaruhi oleh faktor genetis sebagaimana dilaporkan 
oleh (Chaendaekattu dan Mydin, 2018). Di Indonesia, klon-klon yang memiliki volume kayu karet cukup tinggi antara lain RRIM 600 (0,773 m3/ph), PR $255(0,563 \mathrm{~m} 3 /$ ph), dan BPM 107 (0,437 m3/ph). Volume kayu per hektar yang dihasilkan dari ketiga klon tersebut berkisar 80,44-131,4 m3/ha (Woelan dkk., 2012). Ketersediaan bahan baku karet di Indonesia cukup berlimpah, di Provinsi Sumatera Selatan saja setiap tahun potensi kayu karet mencapai 1,7 juta $\mathrm{m} 3$, sedangkan industri pengolahan kayu karet di wilayah tersebut hanya dapat mengolah $18 \%$ dari potensi kayu karet yang ada (Nancy dkk., 2013). Namun demikian, Boerhendhy dkk. (2003), menyatakan bahwa dalam pengelolaan kayu karet terdapat berbagai kendala di antaranya akses jalan, rendemen kayu rendah, suplai tidak kontinyu, dan lokasi pabrik jauh dari lokasi kebun. Oleh sebab itu, untuk menjamin ketersediaan bahan baku, pabrik pengolahan perlu menjalin kemitraan dengan suplier kayu karet (Agustina dkk., 2013). Hasil analisis yang dilakukan oleh Riadi dkk. (2011), menunjukkan bahwa integrasi usaha mulai pengolahan kayu secara teknis dan ekonomi layak dijalankan dengan indikator kelayakan NPV Rp. 8,6 milyar, IRR 58\%, Net B/C 2,1 dan PBP 1,6 tahun untuk periode usaha 5 tahun.

\section{SIMPULAN}

Dalam kondisi harga karet alam yang rendah diperlukan upaya meningkatkan pendapatan dari kebun karet di samping pendapatan utama dari lateks.Selama masa TBM, areal tanaman karet dapat dimanfaatkan sebagai sumber pendapatan dengan pola tumpangsari selama tajuk antar barisan belum bertemu. Strategi pemilihan jenis komoditi, penyesuaian dengan pola musim permintaan pasar menjadi kunci keberhasilan tumpangsari. Tanaman karet dapat dikelola dengan sistem integrasi karet-ternak. Sapi, kambing dan lebah madu adalah beberapa ternak yang dapat dikembangkan di perkebunan karet sebagai sumber pendapatan nonlateks. Biji karet dapat diolah menjadi tepung pakan, biodiesel, dan areang aktif. Selain itu, limbah cair dari pengolahan lateks dapat diproses untuk mengektraksi kandungan proteinnya.Areal tanaman tua yang akan diremajakan menyimpan potensi kayu yang cukup tinggi. Dengan pengolahan yang tepat, kayu karet dapat digunakan sebagai substitusi kayu hutan. Pemanfaatan sumberdaya nonlateks selain meningkatkan nilai tambah kebun karet juga dapat digunakan sebagai alternatif sumber pendapatan untuk meminimalisir dampak harga karet yang rendah. Dibutuhkan dukungan penguatan kelembagaan ekonomi, seperti pengolahan, penyimanan dan pemasaran hasil diversifikasi usaha. Kelembagaan tersebut dapat mempermudah petani dalam mengembangkan usahanya. Di masa yang akan datang, diharapkan diversifikasi usaha perkebunan karet dapat berorientasi pasar yag kuat, dan secara ekonomi layak untuk diusahakan.

\section{DAFTAR PUSTAKA}

A'ini, Y., \& Jannah, W. (2016). Pengaruh Penurunan Harga Karet Mentah Terhadap Daya Beli Masyarakat di Pasar Desa Pasir Jaya. Jurnal IImiah Cano Ekonomos, 5(2), 125-132.

Abduh, M. Y., Manurung, R., \& Heeres, H. J. (2017). Techno-economic Analysis for Small Scale Production of Rubber Seed Oil and Biodiesel in Palangkaraya, Indonesia. Journal of Clean Energy Technologies, 5(4), 268-273. https://doi.org/10.18178/ JOCET.2017.5.4.381

Agarry, S. E., \& Owabor, C. N. (2012). Evaluation of the Adsorption Potential of Rubber (Hevea brasiliensis) Seed Pericarp-Activated Carbon in Abattoir Wastewater Treatment and in the Removal of Iron (III) lons from Aqueous Solution. Nigerian Journal of Technology, 31(3), 346-358. 
Aguihe, P. C., Kehinde, A. S., Ivan, O. C., \& Eiko, M. A. (2017). Evaluation of Processing Methods of Rubber (Hevea brasiliensis) Seed Meal for Use as a Feed Ingredient for Broiler Chickens. Journal of Poultry Research, 14(1), 20-27.

Agustina, D. S. (2012). Pemanfaatan kayu karet di beberapa negara produses karet alam dunia. Warta Perkaretan, 31(2), 85. https://doi.org/10.22302/ ppk.wp.v31i2.270

Agustina, D. S., Herlinawati, E., \& Aji, M. (2013). Financial Analyses on d4 Tapping as Alternative to d3 in Rubber Plantation of South Sumatra. International Rubber Conference 2017, 841-849.

Agustina, D. S., Herlinawati, E., \& Nugraha, I. S. (2017). Kajian Ekonomi Penundaan Buka Sadap Sebagai Solusi untuk Menghadapi Harga Karet Rendah. Warta Perkaretan, 36(1), 75-82. https://doi. org/10.22302/ppk.wp.v36i1.258

Agustina, D. S., Syarifa, L. F., \& Nancy, C. (2013). Kajian Kelembagaan dan Kemitraan Pemasaran Kayu Karet di Provinsi Sumatera Selatan. Jurnal Penelitian Karet, 31(1), 54. https:// doi.org/10.22302/jpk.v31i1.133

Agustina, D. S., Syarifa, L. F., \& Nancy, C. (2016). Kajian Prospek Bisnis Pembibitan Karet di Provinsi Sumatera Selatan. Jurnal Penelitian Karet, 34(2), 225-236. https://doi. org/10.22302/jpk.v34i2.227

Ahmad, J., Yusup, S., Bokhari, A., \& Kamil, R. N. M. (2014). Study of Fuel Properties of Rubber Seed Oil Based Biodiesel. Energy Conversion and Management, 78, 266-275. https://doi.org/10.1016/j. enconman.2013.10.056
Andriyanto, M., Dalimunthe, C. I., \& Sembiring, Y. R. V. (2017). Pemanfaatan Bangun-bangun (Coleus amboinicus) di Gawangan TBM Karet untuk Pengendalian Jamur Akar Putih dan Kesuburan Tanah. Warta Perkaretan, 36(2), 137-146.

Anis, D., Zaidi, a G., Khudzir, I., Iqbaldin, M. N., Osman, U. M., \& Nawawi, W. I. (2014). Production of Rubber Seed Pericarp Based Activated Carbon Using Microwave-Induced Different Chemical Activating Agent. International Journal of Scientific and Research Publications, 4(7), 1-8.

Araújo, L. A., Melo-Reis, P. R., Mrue, F., Gomes, C. M., Oliveira, M. A. P., Silva, H. M., Alves, M. M., \& SilvaJúnior, N. J. (2017). Protein from Hevea brasiliensis "Hev b 13" Latex Attenuates Systemic Inflammatory Response and Lung Lesions in Rats with Sepsis. Brazilian Journal of Biology, 78(2), 271-280. https://doi. org/10.1590/1519-6984.06316

Arsad, E. (2009). Kayu Karet Sebagai Substitusi Kayu Hutan Alam untuk Industri. Jurnal Riset Industri Hasil Hutan, 1(1), 31-37. https://doi. org/10.24111/jrihh.v1i1.871

Aulia, Aprilianda, Arsyad, F. S., \& Johan, A. (2019). Temperature Carbonization Effect on the Quality of Activated Carbon Based on Rubber Seed Shell. Journal of Physics: Conference Series, 1282(1), 012043. https://doi.org/10.1088/17426596/1282/1/012043

Badan Pusat Statistik. (2019). Statistik Karet Indonesia. Badan Pusat Statistik. 
Baffes, J., \& Wu, J. (2018). Raw Materials Outlook: Cotton, Rubber Prices to Stabilize in 2019. World Bank Blogs. http://blogs.worldbank.org/ developmenttalk/raw-materialsoutlook-cotton-rubber-pricesstabilize-2019

Boerhendhy, I., Nancy, C., \& Gunawan, A. (2003). Prospek dan Potensi Pemanfaatan Kayu Karet sebagai Substitusi Kayu Alam. IImu Dan Teknologi Kayu Tropis, 1(1), 35-46.

Boerhendy, I., Agustina, D. S., \& Setiono. (2012). Paket Teknologi Karet untuk Mempersingkat Masa Tanaman Belum Menghasilkan Kurang dari Empat Tahun. Prosiding Konferensi Nasional Karet, Yogyakarta 19 - 20 September 2012, 269-278.

Borhan, A., Abdullah, N. A., Rashidi, N. A., \& Taha, M. F. (2016). Removal of $\mathrm{Cu} 2+$ and $\mathrm{Zn} 2+$ from Single Metal Aqueous Solution Using Rubber-Seed Shell Based Activated Carbon. Procedia Engineering, 148, 694-701. https://doi.org/10.1016/j. proeng.2016.06.571

Chaendaekattu, N., \& Mydin, K. K. (2018). Inheritance Pattern and Genetic Correlations Among Growth and Wood Quality Traits in Para rubber tree (<i>Hevea brasiliensis $>/ i>)$ and Implications for Breeding. Tree Genetics and Genomes, 14(5). https://doi.org/10.1007/s11295-0181278-5

Darmawan, N., Fitrianti, F., \& Dewi, I. R. (2017). Lateks Karet Alam Bebas Protein Menggunakan Natrium Hidroksida. Prosiding Seminar Nasional Kulit, Karet Dan Plastik Ke-6, Yogyakarta 25 Oktober 2017, 211-222.
Dewi, D., Harianto, Mangkuprawira, S., \& Kusnadi, N. (2010). Peran Pengembangan Sumber Daya Manusia dalam Peningkatan Pendapatan Rumah Tangga Petani di Derah Istimewa Yogyakarta. Forum Pascasarjana, 33(3), 155-164.

Dianita, R. (2012). Keragaman Fungsi Tanaman Pakan Dalam Sistem Perkebunan. Pastura, 2(2), 66-69.

Diwyanto, K., Priyanti, A., \& Saptati, R. A. (2007). Prospek Pengembangan Usaha Peternakan Pola Integrasi. Sains Peternakan, 5(2), 26-33. https://doi.org/10.20961/sainspet. v5i2.4924

Ferreira, M., Mendonça, R. J., CoutinhoNetto, J., \& Mulato, M. (2009). Angiogenic Properties of Natural Rubber Latex Biomembranes and the Serum Fraction of Hevea brasiliensis. Brazilian Journal of Physics, 39(3), 564-569. https://doi.org/10.1590/ S0103-97332009000500010

Fortuna, D., Rahimsyah, A., \& Puspitasari, Y. (2015). Degradation of Acid Cyanide Poison in Rubber Seed (Hevea Brasiliensis) After Treatment with Rice Husk Ash. International Journal on Advanced Science, Engineering and Information Technology, 5(4), 291-293. https:// doi.org/10.18517/ijaseit.5.4.540

Gaba, S., Lescourret, F., Boudsocq, S., Enjalbert, J., Hinsinger, P., Journet, E. P., Navas, M. L., Wery, J., Louarn, G., Malézieux, E., Pelzer, E., Prudent, M., \& Ozier-Lafontaine, $\mathrm{H}$. (2015). Multiple Cropping Systems as drivers for providing multiple ecosystem services: from concepts to design. Agronomy for Sustainable Development, 35(2), 607-623. https://doi.org/10.1007/s13593-0140272-z 
Hayashi, Y. (2009). Production of natural rubber from Para rubber tree. Plant Biotechnology, 26, 67-70. https://doi.org/10.5511/ plantbiotechnology.26.67

Hirohata, N. (2015). A survey on the competitiveness of natural rubber companies in Mekong sub-region. IFEAMA SPSCP, 4, 72-79. http:// ifeama.org/ifeamaspscp/selected papers/12th in Hanoi/12th 07 Hirohata_Final .pdf

Hirohata, N., \& Fukuyo, K. (2011). Comparative study of large-scale investment in plantation in least developed countries applying the investment profitability analysis model. Proceedings of the 8Th International Conference on Innovation and Management, 1 , 370-374.

Hutapea, Y., Suparwoto, S., Suryana, Y., \& Hutabarat, P. (2019). Nilai tambah berat badan sapi berdasarkan pemberian pakan di kawasan perkebunan karet. Prosiding Seminar Nasional Lahan Suboptimal, Palembang 4-5 September 2019, 62-70.

Ismanto, A., \& Saputro, Y. D. (2014). Analisis kimia kayu karet (Hevea brasiliensis Muell. Arg.) diawetkan secara tradisional. Jurnal Sains Natural Universitas Nusa Bangsa2, 4(2), 181-186.

Jisieike, C. F., \& Betiku, E. (2020). Rubber seed oil extraction: effects of solvent polarity, extraction time and solid-solvent ratio on its yield and quality. Biocatalysis and Agricultural Biotechnology, 24(February), 101522. https://doi.org/10.1016/j. bcab.2020.101522
Junior, H. de J. E., Ohto, J. M., da Silva, L. L., Lara Palma, H. A., \& Ballarin, A. W. (2015). Potential of rubberwood (Hevea brasiliensis) for structural use after the period of latex extraction: a case study in Brazil. Journal of Wood Science, 61(4), 384-390. https://doi. org/10.1007/s10086-015-1478-7

Kanokwiroon, K., Teanpaisan, R., Wititsuwannakul, D., Hooper, A. B., \& Wititsuwannakul, R. (2008). Antimicrobial activity of a protein purified from the latex of Hevea brasiliensis on oral microorganisms. Mycoses, 51(4), 301-307. https://doi.org/10.1111/j.14390507.2008.01490.x

Karima, R. (2015a). Kualitas minyak biji karet sebagai minyak pangan alternatif pasca penghilangan $\mathrm{HCN}$. Jurnal Riset Industri Hasil Hutan, 7(2), 17. https://doi.org/10.24111/ jrihh.v7i2.1227

Karima, R. (2015b). Pengaruh perendaman dan perebusan terhadap kadar $\mathrm{HCN}$ pada biji karet. Jurnal Riset Industri Hasil Hutan, 7(1), 39. https://doi. org/10.24111/jrihh.v7i1.855

Kerche-Silva, L. E., Cavalcante, D. G. S. M., \& Job, A. E. (2018). Natural rubber latex biomaterials in bone regenerative medicine. In Biomaterials in Regenerative Medicine: Vol. i (Issue tourism, p. 13). InTech. https://doi.org/10.5772/ intechopen.69855

Kouassi, G. F., Koné, G. A., Good, M., Assidjo, N. E., \& Kouba, M. (2020). Effect of Hevea brasiliensis seed meal or Euphorbia heterophylla seed supplemented diets on performance, physicochemical and sensory properties of eggs, and egg yolk fatty acid profile in guinea fowl (Numida meleagris). Poultry Science, 99(1), 342-349. https://doi.org/10.3382/ps/ pez500 
Kughur, P. G. (2012). The effects of herbicides on crop production and environment in Makurdi Local Government Area of Benue State, Nigeria. Journal of Sustainable Development in Africa, 14(4), 206216.

Le, H. N. T., Imamura, K., Watanabe, N., Furuta, M., Takenaka, N., Boi, L. Van, \& Maeda, Y. (2018). Biodiesel production from rubber seed oil by transesterification using a co-solvent of fatty acid methyl esters. Chemical Engineering \& Technology, 41(5), 1013-1018. https://doi.org/10.1002/ ceat. 201700575

Lee, S. W., \& Wendy, W. (2017). Malaysian rubber (Hevea brasiliensis) seed as alternative protein source for red hybrid tilapia, Oreochromis sp., farming. AACL Bioflux, 10(1), 32-37.

Liengprayoon, S., Vaysse, L., Jantarasunthorn, S., Wadeesirisak, K., Chaiyut, J., Srisomboon, S., Musigamart, N., Roytrakul, S., Bonfils, F., Char, C., \& Bottier, C. (2017). Fractionation of Hevea brasiliensis latex by centrifugation: (i) a comprehensive description of the biochemical composition of the 4 centrifugation fractions. Proceeding of International Rubber Conference, Jakarta 18-20 October 2017, 645660. http://totallab.com/cliqs/

Liu, H., Yang, X., Blagodatsky, S., Marohn, C., Liu, F., Xu, J., \& Cadisch, G. (2019). Modelling weed management strategies to control erosion in rubber plantations. Catena, 172, 345-355. https://doi.org/10.1016/j. catena.2018.08.041

Malaysian Rubber Board. (2019). Natural Rubber Statistic 2018. http://www. Igm.gov.my/nrstat/Statistics Website 2018 (Jan-Dec).pdf
Mooibroek, H., \& Cornish, K. (2000). Alternative sources of natural rubber. Appl Microbiol Biotechnol, 53(4), 355-365.

Nadarajah, R. Y., Mohammad, R., \& Mohamad, M. (2018). Rubber seed shells (Hevea brasiliensis): an adsorbent used for the removal of Rhodamine B dye. ARPN Journal of Engineering and Applied Sciences, 13(24), 9311-9317.

Nancy, C., Agustina, D. S., \& Syarifa, L. F. (2013). Potensi kayu hasil peremajaan karet rakyat untuk memasok industri kayu karet: studi kasus di Provinsi Sumatera Selatan. Jurnal Penelitian Karet, 31(1), 6878. https://doi.org/10.22302/jpk. v31i1.134

Nian-Yian, L., Peng, W. L., Mohd-Setapar, S. H., Idham, Z., Yunus, M. A. C., \& Muhamadb, I. I. (2014). Application of rubber (hevea brasiliensis) seeds oil extracted using supercritical carbon dioxide in cosmetics. Jurnal Teknologi (Sciences and Engineering), 69(4), 55-59. https:// doi.org/10.11113/jt.v69.3174

Nugrahani, M. O., Rouf, A., Aji, Y. B. S., Widyasari, T., \& Rinojati, N. D. (2017). Kombinasi sisten sadap frekuensi rendah dan penggunaan stimulan untuk optimasi produksi dan penurunan biaya penyadapan di panel BO. Jurnal Penelitian Karet, 35(1), 59-70. https://doi. org/10.22302/ppk.jpk.v1i1.350

Nugroho, P. A., Istianto, Fairuzah, Z., \& Karyudi. (2009). Pengaruh tanaman sela ubi kayu terhadap pertumbuhan tanaman karet belum menghasilkan dan pengurasan hara tanah. Jurnal Penelitian Karet, 27(1), 64-75. 
Oluodo, L. A., Huda, N., \& Komilus, C F. (2018). Potential utilization of rubber seed meal as feed and food. International Journal of Engineering \& Technology, 4(43), 66-71.

Omo-lkerodah, E. E., Omokhafe, K. O., Akpobome, F. A., \& Mokwunye, M. U. (2009). An overview of the potentials of natural rubber (Hevea brasiliensis) engineering for the production of valuable proteins. African Journal of Biotechnology, 8(25), 7303$7307 . \quad$ https://doi.org/10.5897/ AJB2009.000-9564

Pagketanang, T., Artnaseaw, A., Wongwicha, P., \& Thabuot, M. (2015). Microporous activated carbon from $\mathrm{KOH}$-activation of rubber seedshells for application in capacitor electrode. Energy Procedia, 79, 651-656. https://doi.org/10.1016/j. egypro.2015.11.550

Pagketanang, T., Wongwicha, P., \& Thabuot, M. (2015). Characteristics of activated carbon produced from rubber seed shell by using different methods of chemical activation with $\mathrm{KOH}$. Applied Mechanics and Materials, 781, 659-662. https:// doi.org/10.4028/www.scientific.net/ AMM.781.659

Pai, A. V. (2019). Recent trends in natural rubber. Geojit Foresight. https://blog. geojit.com/recent-trends-in-naturalrubber/

Perumal, V., Geetha, N., Palanivel, S., \& Thulaseedharan, A. (2013). Natural rubber producing plants: An overview. African Journal of Biotechnology, 12(12), 1297-1310. https://doi.org/10.5897/AJBX12.016

Priyadarshan, P. M. (2011). Biology of Hevea Rubber. CAB International. https://doi.org/10.1007/978-3-31954506-6
Razak, S. B. A., Aziz, A. A., Ali, N. A., Ali, M. F., \& Visser, F. (2016). The sustainable integration of meliponiculture as an additional income stream for rubber smallholders in Malaysia. $C R I$ \& IRRDB International Rubber Conference, Siem Reap, Cambodia, 21 - 22 November 2016., 143-156.

Riadi, F., Machfud, Bantacut, T., Sailah, I., \& Marimin. (2011). Pengembangan agroindustri berbasis kayu karet. Agri-Tek, 12(2), 96-108.

Rinojati, N. D., Putra, R. C., Afifah, E., \& Muliawansyah, I. (2016). Analisis efisiensi usahatani pisang di antara tanaman karet: studi kasus di Kebun Cibungur, PTPN VIII Jawa Barat. Warta Perkaretan, 35(1), 37-48. https://doi.org/10.22302/ppk. wp.v35i1.79

Rinojati, N. D., Rouf, A., Aji, Y. B. S., Nugrahani, M. O., \& Widyasari, T. (2018). Peningkatan produksi dan analisis finansial pada buka sadap lilit batang $>45 \mathrm{~cm}$ untk menghadapi harga karet rendah. Jurnal Penelitian Karet, 35(2), 159-170. https://doi. org/10.22302/ppk.jpk.v35i2.321

Rodrigo, V. H. L., Silva, T. U. K., \& Munasinghe, E. S. (2004). Improving the spatial arrangement of planting rubber (Hevea brasiliensis Muell. Arg.) for long-term intercropping. Field Crops Research, 89(2-3), 327-335. https://doi.org/10.1016/j. fcr.2004.02.013

Rusdiana, S., Hutasoit, R., \& Sirait, J. (2015). Analisis ekonomi usaha sapi potong di lahan perkebunan sawit dan karet. SEPA: Jurnal Sosial Ekonomi Pertanian Dan Agribisnis, 12(2), 146-155. 
Rusdiana, S., \& Praharani, L. (2018). Pengembangan peternakan rakyat sapi potong: kebijakan swasembada daging sapi dan kelayakan usaha ternak. Forum Penelitian Agro Ekonomi, 36(2), 97-116. https://doi. org/10.21082/fae.v36n2

Rusdiana, S., \& Soeharsono. (2017). Farmer group performance Bali cattle in Luwu District East: the economic analysis. The International Journal of Tropical Veterinary and Biomedical Research, 2(1), 18-29. https://doi. org/10.21157/ijtvbr.v2i1.8634

Rusdiana, S., Wibowo, B., \& Praharani, L. (2010). Penyerapan sumberdaya manusia dalam analisis fungsi usaha penggemukan sapi potong rakyat di pedesaan. Seminar Nasional Teknologi Peternakan Dan Veteriner, 453-460.

Sahuri. (2017a). Pengembangan tanaman jagung (Zea mays L.) di antara tanaman karet belum menghasilkan. Analisis Kebijakan Pertanian, 15(2), 113-126.

Sahuri. (2017b). Uji adaptasi sorgum manis sebagai tanaman sela di antara tanaman karet belum menghasilkan. Jurnal Penelitian Karet, 35(1), 2338. https://doi.org/10.22302/ppk.jpk. v1i1.286

Sahuri. (2017c). Pengaturan pola tanam karet (Hevea brasiliensis Muell. Arg.) untuk tumpang sari jangka panjang. Jurnal IImu Pertanian Indonesia, 22(1), 46-51. https://doi. org/10.18343/jipi.22.1.46

Sahuri. (2019). Teknologi tumpangsari karet-tanaman pangan: kendala dan peluang pengembangan berkelanjutan. Jurnal Penelitian Dan Pengembangan Pertanian, 38(1), 23-34. https://doi.org/10.21082/jp3. v38n1.2019.p23-34
Sahuri, S., Cahyo, A. N., \& Nugraha, I. S. (2016). Pola tumpang sari karet-padi sawah pada tingkat petani di lahan pasang surut (studi kasus di Desa Nusantara, Kecamatan Kecamatan Air Sugihan, Kabupaten OKI, Provinsi Sumatera Selatan). Warta Perkaretan, 35(2), 107-120. https:// doi.org/10.22302/ppk.wp.v35i2.94

Sahuri, S., \& Rosyid, M. J. (2015). Analisis usahatani dan optimalisasi pemanfaatan gawangan karet menggunakan cabai rawit sebagai tanaman sela. Warta Perkaretan, 34(2), 77-88. https://doi. org/10.22302/ppk.wp.v34i2.250

Santoso, L., \& Agusmansyah, H. (2011). Pengaruh substitusi tepung kedelai dengan tepung biji karet pada pakan buatan terhadap pertumbuhan ikan bawal air tawar (Colossoma macropomum). Berkala Perikanan Terubuk, 39(2), 41-50.

Saputra, J. (2018). Strategi pemupukan tanaman karet dalam menghadapi harga karet yang rendah. Warta Perkaretan, 37(2), 75-86. https://doi. org/10.22302/ppk.wp.v37i2.584

Sari, H. F. M., \& Rahayu, S. S. B. (2013). Jenis-Jenis gulma yang ditemukan di perkebunan karet (Hevea brasiliensis Roxb.) Desa Rimbo Datar Kabupaten 50 Kota Sumatera Barat. Biogenesis: Jurnal IImiah Biologi, 1(1), 28-32. https://doi.org/10.24252/bio.v1i1.444

Setyawardani, D. A., Alkautsar, H. S., \& Fadhilah, U. R. (2013). Pengolahan biji karet sebagai bahan baku pembuatan minyak pangan (edible oil). Ekuilibium, 12(1), 23-26. https://doi.org/10.20961/ekuilibrium. v12i1.2174

Suheryanto, D. (2010). Pengaruh konsentrasi cupri sulfat terhadap keawetan kayu karet. Prosiding Seminar Nasional Rekayasa Kimia Dan Proses 2010, 1-12. 
Sundari, T., \& Purwantoro. (2014). Kesesuaian genotipe kedelai untuk tanaman sela di bawah tegakan pohon karet. Penelitian Pertanian Tanaman Pangan, 33(1), 44-53.

Suprayudi, M. A., Irawan, W. S., \& Utomo, N. B. P. (2015). Evaluasi tepung bungkil biji karet difermentasi cairan rumen domba pada pakan ikan patin. Jurnal Akuakultur Indonesia, 13(2), 146. https://doi.org/10.19027/ jai.13.146-151

Susila, I. W. (2009). Pengembangan proses produksi biodiesel biji karet metode non-katalis superheated methanol pada tekanan atmosfir. Jurnal Teknik Mesin, 11(2), 115-124. https://doi. org/10.9744/jtm.11.2.pp.

Sussman, G. L., Beezhold, D. H., \& Kurup, V. P. (2002). Allergens and natural rubber proteins. Journal of Allergy and Clinical Immunology, 110(2), S33-S39. https://doi.org/10.1067/ mai.2002.124969

Syamsunarno, M. B., \& Sunarno, M. T. D. (2014). Kajian biji karet (Hevea brasiliensis) sebagai kandidat bahan baku pakan ikan. Jurnal IImu Pertanian Dan Perikanan, 3(2), 135142.

Syarifa, L. F., Agustina, D. S., Nancy, C., \& Supriadi, M. (2016). Dampak rendahnya harga karet terhadap kondisi sosial ekonomi petani karet di Sumatera Selatan. Jurnal Penelitian Karet, 34(1), 119. https:// doi.org/10.22302/jpk.v0i0.218

Tahir, H., \& Misran, M. (2019). Natural rubber latex (NRL) waste protein purified at various $\mathrm{pH}$ condition and metal extraction studies. Journal of Physics: Conference Series, 1349(1), 012062. https://doi.org/10.1088/17426596/1349/1/012062
Teoh, Y. P., Don, M. M., \& Ujang, S. (2011). Assessment of the properties, utilization, and preservation of rubberwood (Hevea brasiliensis): a case study in Malaysia. Journal of Wood Science, 57(4), 255-266. https://doi.org/10.1007/s10086-0111173-2

Tistama, R., Minati, W., Darojat, M. R., \& Dalimunthe, C. I. (2017). Protein lateks Hevea brasiliensis sebagai fungisida untuk pengendalian penyakit tanaman. Jurnal Penelitian Karet, 35(1), 39-48. https://doi. org/10.22302/ppk.jpk.v1i1.294

Towaha, J., \& Daras, U. (2013). Peluang pemanfaatan kayu karet (Hevea brasiliensis) sebagai kayu industri. Warta Penelitian Dan Pengembangan Tanaman Industri, 19(2), 26-31.

Ulfah, M., Mulyazmi, M., Burmawi, B., Praputri, E., Sundari, E., \& Firdaus, F. (2018). Biodiesel production methods of rubber seed oil: A review. IOP Conference Series: Materials Science and Engineering, 334(1), 1-7. https://doi.org/10.1088/1757899X/334/1/012006

Vachlepi, A. (2015). Produksi medium density fibreboard (MDF) dari kayu karet di Sumatera Selatan: potensi, mutu dan proses pengolahannya. Warta Perkaretan, 34(2), 177. https:// doi.org/10.22302/ppk.wp.v34i2.259

Vachlepi, A. (2019). Prospek pemanfaatan kayu karet sebagai bahan baku pembuatan pulp. Warta Perkaretan, 1(1), 47-60. https://doi.org/10.22302/ ppk.wp.v1i1.593

Vachlepi, A., Suwardin, D., \& Hanifarianty, S. (2015). Pengawetan kayu karet menggunakan bahan organik dengan teknik perendaman panas. Jurnal Penelitian Karet, 33(1), 57. https:// doi.org/10.22302/jpk.v33i1.171 
Valdes, Y. B. (2016). El Rol De Las Arvenses Como Componente En La Biodiversidad De Los Agroecosistemas. Cultivos Tropicales, 37(4), 34-56. https://doi. org/10.13140/RG.2.2.10964.19844

Van Parijs, J., Broekaert, W. F., Goldstein, I. J., \& Peumans, W. J. (1991). Hevein: an antifungal protein from rubbertree (Hevea brasiliensis) latex. Planta, 183(2), 258-264. https://doi. org/10.1007/BF00197797

Wang, X., Shi, M., Lu, X., Ma, R., Wu, C., Guo, A., Peng, M., \& Tian, W. (2010). A method for protein extraction from different subcellular fractions of laticifer latex in Hevea brasiliensis compatible with 2-DE and MS. Proteome Science, 8, 1-10. https:// doi.org/10.1186/1477-5956-8-35

Widyarani, Coulen, S. C. W., Sanders, J. P. M., \& Bruins, M. E. (2017). Valorisation of proteins from rubber tree. Waste and Biomass Valorization, 8(4), 1027-1041. https://doi.org/10.1007/ s12649-016-9688-9

Widyarani, Sari, Y. W., Ratnaningsih, E., Sanders, J. P. M., \& Bruins, M. E. (2016). Production of hydrophobic amino acids from biobased resources: wheat gluten and rubber seed proteins. Applied Microbiology and Biotechnology, 100(18), 79097920. https://doi.org/10.1007/ s00253-016-7441-8

Widyasari, T., Nugrahani, M. O., \& Sumarmadji. (2017). Financial feasibility of low frequency tapping systems to deal with the business challenge of rubber plantation in Indonesia. International Rubber Conference 2017, 831-840.
Woelan, S., Siagian, N., Sayurandi, S., \& Pasaribu, S. A. (2012). Potensi kayu karet hasil peremajaan di tingkat perusahaan perkebunan. Warta Perkaretan, 31(2), 75. https://doi. org/10.22302/ppk.wp.v31i2.269

Wongsiri, S., Pyramarn, K., Leepitakrat, S., \& Aemprapa, S. (1999). Rubber: a potential major honey plant in Thailand. Bee World, 80(4), 187190. https://doi.org/10.1080/000577 2x.1999.11099454

Yan, K. Z., Zaini, M. A. A., Arsad, A., \& Nasri, N. S. (2019). Rubber seed shell based activated carbon by physical activation for phenol removal. Chemical Engineering Transactions, 72(October 2018), 151-156. https:// doi.org/10.3303/CET1972026

Yatno, Murni, R., Nelwida, \& Yani, E. N. (2015). Kandungan asam aianida, bahan kering dan bahan organik tepung biji karet hasil pengukusan. Jurnal IImiah IImu-IImu Peternakan Universitas Jambi, 18(2), 58-65.

Yu, L. J., Chi, C. W. Y., Tangavaloo, V., Lim, K. W., \& A Tarawneh, M. (2019). Protein reduction of natural rubber films through leaching solvent. MATEC Web of Conferences, 268, $01011 . \quad$ https://doi.org/10.1051/ matecconf/201926801011

Zakariyya, F., Puspitasari, N., \& Prawoto, A. A. (2016). Ragam model pola tumpangsari kakao-karet. Warta Pusat Penelitian Kopi Dan Kakao Indonesia, 28(1), 19-28. 